\title{
The Impact of Foreign Direct Investment (FDI) on Technological Progress and Productivity Growth - A Case Study of Chinese Industries
}

\author{
Lan $\mathrm{Xu}^{*}$ \\ Business School, East China University of Science and Technology, China
}

*Corresponding Author: Lan Xu, Business School, East China University of Science and Technology, China

\begin{abstract}
This paper adopts the principle of Malmquist productivity growth index calculation to analyze the Chinese inward foreign direct investment (IFDI) and outward foreign direct investment (OFDI) for recent 12 years and their technological spillovers to the Chinese economy. Especially it provides a comparison among Chinese different industries and sectors. To this end, the paper uses the two-stage (parametric and nonparametric) optimization approach to estimate the elasticity of China's IFDI and OFDI that contribute to the development of domestic technological progress and productivity growth. Besides, in order to appropriately evaluate the effect of technological spillovers, this paper also utilizes the component of technological progress of Malmquist productivity growth index to measure total factor productivity (TFP) instead of Solow residual. Finally, this paper provides a comparative analysis on the effect of technological spillover across country's different industries and sectors from both the inward foreign direct investment (IFDI) and the outward foreign direct investment (OFDI). As a result, it concludes that China has attracted a significant amount of high technologies through foreign direct investment (FDI), which plays a great role in promoting the development of China's economy in recent decades. On the other side, a large-scale of outward foreign direct investment (OFDI) of Chinese enterprises is still in its infancy. Thus, the reverse technological spillover of OFDI to China is not obvious at a current stage or even has a negative impact.
\end{abstract}

Keywords: Foreign Direct Investment; Technological Spillover; Productivity Growth; Scale Effect; Total Factor Productivity; China's Studies

\section{INTRODUCTION}

In an increasingly competitive international economic environment, a country, a region or an industry to pursue continuously sustainable development, the only way is to constantly improve comprehensive competitive abilities. As the core of comprehensive competitive capability, the economic efficiency or productivity growth mainly includes factors of production growth and technological progress, which are combined factors for the national economic growth. Factors of production growth, hereinafter referred to as elements of growth, are the output efficiency of production factors, such as labor, capital and land, after considering the scale of an input investment. Technological progress is due to an investment of research and development, accumulation of knowledge, ascension of human capital stock as a result in improving innovative ability and production efficiency. The combination of the two elements intertwined internally and organically is finally characterized by an improvement of comprehensive competitiveness and economic efficiency.

Rose in the 1980s, some economists, represented by P. Romer (1986)[1] and R. Lucas (1988)[2], of the new economic growth theory emphasize that the investment and deepening of capitals endogenizes technological progress, while the technological progress is the source of a long-term economic growth. As the world economy transformed from a traditional market economy to an open market economy, many countries especially developed countries endogenize technological progress not only by domestic production investment and capital deepening, but also through the flow and configuration of international production factors, moreover, the scale is continuously growing. As a result, the capital deepening leads to an increase of international foreign direct investment (FDI), 
while the FDI continuously gives birth to the technical innovation and technological progress, and therefore promotes a long-term economic growth.

In this paper, it considers the role of FDI to technological progress from two aspects: one is an inward foreign direct investment (IFDI), namely, the technological progress of a host country in the process of foreign direct investment and production by directly transferring stocks of advanced techniques and accumulated knowledge, as well as the technological progress through innovation and imitation in the progress of investment and production of IFDI to the host country. The second is an outward foreign direct investment (OFDI), that is, the technological progress incurred by new and endogenous technologies to the investing country in the progress of foreign direct investment due to continuously capital spending and investment domestically.

The effect of technological spillovers to the host country for an inward foreign direct investment (IFDI) is mainly reflected by two aspects, one is a horizontal spillover effect, namely the impact of production efficiency within the same industry of host countries; Second is a vertical spillover effect, that is, the impact on production efficiency of enterprises along an industrial chain of the host country (Macdougall, 1960)[3]. Traditionally in the international direct investment, multinational companies, for the purpose of realizing an optimal resource allocation, will choose to use their own superior technologies and seek to cooperate with counter-partner enterprises in the same industry of the host country, which can lead to a technological spillover horizontally to local enterprises within the same industry, such effect is usually referred as a horizontal technological spillover effect. The horizontal technological spillover effect is further divided into two types, one is an outside transformed effect, and another is an inside transformed effect (Lichtenberg, 1996)[4]. The outside transformed investment of IFDI has better positive technological spillover effect than the inside transformed investment to enterprises of the host country, thus in turn make the host country to improve a technological level and promote an economic growth fast. The reason is that for the inside transformed investment of IFDI, investors pay more attentions to a comparative advantage of the host country, often intending to take an advantage of their own superior technologies to make cooperation with enterprises of the host country. Thus the purpose of foreign investment is to obtain better economic resources from the host country in order to service investing countries' own interests, rather than to spread advanced technologies to the host country. On the other hand, the outside transformed IFDI tends to transfer domestic obsolete industries, reallocate industrial structure in a more reasonable frame, which by contrast is favorable for the host country to absorb advanced technologies from investing countries. Furthermore, the vertical spillover effect can also be divided into a forward-linked spillover effect and a backward-linked spillover effect (Rodriguez, 1996)[5]. The forward-linked spillover effect is technological spillover to the host country caused by a linkage between foreign direct investors and local downstream companies along the same industrial chain. On the other side, the backward-linked spillover effect is the technological spillover effect also to the host country but due to a connection between foreign direct investors and local upstream enterprises along a same industrial chain. Therefore, the vertical technological spillover effect is a phenomenon embodied by the backward-linked technological spillover when investing enterprises provide production equipments, product-quality improvement information, innovative techniques, assistances of purchasing raw materials, training programs for the hosting company's staff, and other sorts of activities to raw material suppliers of host countries. Besides, it is also embodied by the forwardlinked technological spillover when investing companies provide auxiliaries to downstream distributors of host countries, finding new customers and other related supporting services. So effects of technological spillover from foreign investors to the host county are different in terms of different counter partners, whether are upstream or downstream enterprises along the same industrial chain. For upstream enterprises of the host country, the technological spillover may help cost-saving in production expenditures, improving production efficiency, thus to reduce prices of raw materials, so is also called "price effect"; for downstream enterprises of host countries, the technological spillover may have an effect of enhancing competitive abilities, improving production efficiencies, reducing product prices, thus ensures investing companies to retain market power in the host country. So is also known as "competitive effect". Obviously, the foreign direct investment not only imposes the effect of technological spillover on the counter-partnership enterprises within the same industry of the host 
country, but also accelerates production efficiency of enterprises in other industries. However, for the purpose of safeguarding their own monopolistic power and maintaining excessive profits, investing companies of FDI seldom voluntarily provide advanced technologies that may spillover to the host country. Therefore, it is generally believed that the vertical spillover effect of FDI to host countries has a far-more profound significance.

On the other hand, the reversed technological spillover of an outward foreign direct investment (OFDI) is an effect of technological spillover on investing countries from their own investment activities. It mainly occurs as a strategic asset-seeking typed foreign direct investment in host countries with relatively high technological levels. Knowing that a technological level of developed countries is usually higher than that of developing countries, as a result, the reversed technological spillover shows an obvious positive effect on promoting investing countries' technological levels if the foreign direct investment by developing countries is targeted to developed countries, especially that of a strategic asset-seeking typed investment. Particularly to say, the investors' reversed technological spillover of investment can experience two stages: in the first stage, subsidiaries of investing companies obtain technological spillovers from host countries by purchasing by-products from local suppliers, enjoying after-sale services, hiring skilled workers and management personnel. In the second stage, subsidiaries of investing enterprises transfer advanced technologies and newly obtained knowledge that are overflow from host countries to domestic parent companies through an internal conductive mechanism in a lawful way. Finally, these advanced technologies and newly acquired knowledge may further overflow externally to other companies and industries by the parent companies of investing countries, thus in turn cause the sciences and technologies of the whole investing country increase to a higher level. For a developing country such as China, in order to attract more reversed technological spillovers, it is required that foreign direct investment be focused more on developed countries, which is advantageous for the occurrence of technological diffusion and transfer, ensuring that the advanced technologies overflow from the hosting developed countries to investing countries. In this sense, an outward foreign direct investment of developing countries involves three aspects of technological spillovers covering the levels of enterprises, industries and the nation, separately.

Whether it is from an inward foreign direct investment (IFDI) or an outward foreign direct investment (OFDI), the technological spillover to productivity growth is affected by many factors, the main decisive factors among which include technical and geographical gaps of both participants involved in the investment, investing behavior of distributors with high technologies and absorptive capability of recipients for technological spillovers. It is commonly believed that there exists a "threshold effect" between technical gap and technical diffusion of both sides of investing parties (Perez, 1997)[6], sometimes is considered as a non-linear "inverted-U" relationship. Namely, when a technical gap is too large, it is unfavorable for the occurrence of technological diffusion, and the investing enterprises will have an incentive to make an "extrusive effect" that drives out local companies. Only when the technical gap is shortened to a certain level, may the recipients of technological spillovers be able to absorb advanced technologies efficiently. Thus the spillover effect of technological diffusion becomes increasingly obvious as technical gap is gradually reduced. Accordingly, a technological diffusion of international direct investment is often characterized of localization, that is, the impact of technological spillovers on the productivity of recipients will be weakened with an increase of geographic distances between both sides of participants in the investment. From the viewpoints of investors, the investing behaviors, one of influential factors on international direct investment, can be divided into two types, one is a market-oriented form and the other is an export-oriented form. Alternatively to say, one is a technical-using type and the other is a technical-seeking type (Driffield, 2001)[7]. For the market-oriented type, the host country is also considered as products' selling market, while for the export-oriented type, the host country is tend to be considered as producing plants for products. Turn it in another way, for the technical-using typed investment, investing companies often take advantages of their own superior technologies to invest in host countries, while for the technical-seeking typed investment, investing countries are likely to invest in host countries looking for advanced technologies. Therefore, investing companies involved in the market-oriented foreign direct investment tend to purchase raw materials from host countries as many as possible, thus are more often to incur a vertical technological spillover effect in host countries. Obviously, the 
technical-using typed foreign direct investment has played a positive role of technological spillovers to host countries, while the technical-seeking typed foreign direct investment tends to negatively impact on host countries for a diffusion of advanced technologies. In addition, the cooperative form of investing enterprises, whether in the form of sole proprietorship or equity partnership, will also affect the result of technological spillover effect. It is generally assumed that an international direct investment with foreign companies' stake in equity is more inclined to purchasing raw materials in host countries' markets, thus are more likely to have vertical technological spillover effects (Javorcik, 2004)[8]. On the other side, from the recipients' perspective of views, the absorptive capacity of host countries for technological spillovers, including the level of human resources and intensity of R\&D investment, and etc., directly determines the effect of technological spillovers from foreign direct investment. That is, the higher the level of human resources and the intensity of $R \& D$, the stronger the capacity of host countries to absorb advanced technologies, thus the better the technological spillover effect (Cohen \& Levinthal, 1990)[9].

\section{LiteratURE REVIEWS}

\subsection{Traditional Theories of International Investment Research}

Since the 1960s, the academia has come out a number of different views about the international direct investment, such as the wealth effect theory by Mcdougall (1960)[3], the comparison superiority theory by Japanese scholar Kiyoshi Kojima (1987)[10], the monopoly superiority theory by Stephen Hymer (1960)[11] and C.P. Kindleberger (1969)[12], the market internalization theory by British scholars Peter J. Buckley and Mark Casson (1998)[13], A. Rugman and Stephen Yong (2005)[14], and others, the product cycle theory by R. Vernon (1966)[15], and so on. In the late 1970s, a British economist, John H. Dunning (1973)[16] put forward to a compromised theory of international production, the theory of combinations of "Three Advantages", on the basis of summarizing the previous theories, believed that the international multinational investment and management depend mainly on the level of comprehensive combination of the three advantages, i.e., the ownership advantage, the internalization advantage and the location advantage. Since the 1990s, the international investment theory has focused on studying the existence and influential factors of technological spillover effects. Among them, representative scholars include Cohen \& Levinthall (1990)[9], who argue that the R\&D inputs promote technological spillovers and absorptive abilities; Coe \& Helpman (1995)[17], who assume that the technological spillover effect depends on a country's R\&D capital stocks and its transferring channels for spreading technologies; Rodriguez-Clare (1996)[5], who for the first time uses the method of general equilibrium analysis to analyze an impact of international direct investment on the economic growth of host countries; Blomstrom \& Sjoholm (1999)[18], who proposes that the technological gap and the reversed technological spillover effect of OFDI show a nonlinear trend; Lichtenberg \& Potterie (2001)[19], Driffield \& Love (2003)[20], and others, have proved the existence of reversed technological spillover effect for OFDI using various econometric methods. However, these theories on the international direct investment are mainly based on developed countries as research objects, emphasizing on prerequisites of various advantages for foreign direct investment, however, having some limitations in explaining a growing phenomenon of the foreign direct investment by developing countries.

\subsection{Research Reviews of International Investment Theories in Developing Countries}

With a continuous development of global economic integration, foreign direct investment in developing countries grows rapidly, and the proportion of international direct investment increases gradually every year. In recent years, academic studies of foreign direct investment for developing countries have also increased accordingly, which provides a beneficial supplement to traditional investment theories. Among them, it mainly includes a double gap theory by H.B. Chenery and A.M. Sturout (1980)[21], and Bruno, theory of small-scale technologies by Louis T. Wells (1983)[22], theory of technological localization by S. Lall (1983)[23], theory of technological innovation and industrial upgrading by John A. Cantwell and Paz Estrella E. Tolentino (1987)[24], and so on.

Since the reform and opening-up, China's economy has experienced rapid development for more than 30 years, and the international direct investment has transformed from absorption of foreign direct investment only to actively participating in the outward foreign direct investment, which has 
accomplished a strategic transformation from passively implementing the policy of economic globalization to actively following the policy of world economic development. Therefore, domestic scholars have carried out some researches on theories of reversed technological spillover effects regarding the international direct investment extensively in recent years, and have also made remarkable achievements. With regard to these theoretical researches, $\mathrm{Wu}$ Bin and Huang Tao put forward to a theory of "Two Stage Development" that the international direct investment for developing countries may experience depending on the level of resources in the position. In the first stage, the resource level of investing countries is usually lower than host countries, which is the stage for accumulating experiences for developing countries; and in the second stage, the resource level of investing countries exceeds that of host countries, in which enterprises of investing countries seek for high profits. Guo-ming Xian and Rui Yang (1998)[25] emphasize on a theory of "Reversed Two-stage Development" from a different view of economic development that the foreign direct investment of developing countries can also be divided into two stages, but by a reverse order, first to developed countries and second to developing countries. Ya-ming Ma and Yan-gui Zhang (2003)[26] show, from the perspective of technological diffusion, that it is rational for developing countries to make economic growth through foreign direct investment. Qunyang Du and Qin Zhu (2004)[27] put forward a theory of "three advantages of foreign direct investment" suggesting developing countries adopt a technology-seeking typed foreign direct investment. Jian-hua Yin and Xinyue Zhou (2014)[28] establish a "double threshold effect" model to show that there exist a nonlinear relationship between technological gap and the reversed technological spillover effect.

Regarding to these empirical researches, Hong-zhong Liu (2001)[29] argues that China is in the second phase of development cycle of foreign direct investment with a per capita GDP level in accordance with Dunning's theory of an investment development cycle. Minxue Gao and Yingjun Li (2004)[30] think that China's foreign direct investment lags behind its development stage where it should be by using comparative studies for international investment experiences. Others, such as Qiuzhi Xue and Jiqing Zhu (2007)[31], Jianquan Yang \& et.al (2006)[32], Guangjian Zhang \& et.al (2006)[33], analyze the correlation between China's foreign direct investment and economic development by using a variety of economic tools. Wei Zhao, Guangdong $\mathrm{Gu}$ and Yuanqing $\mathrm{He}$ (2006)[34], Jie Bai (2009)[35] and etc. carry out to study the correlation between foreign direct investment and technological progress in China by using a national R\&D spillover model. Jianguang Liu and Jianqing Yang and etc. provide an empirical research on factors of location choices for China's foreign direct investment. Research results by Chunying Zhou (2009)[36], Tong Zhu and Hao Cui (2011)[37], Tingting Feng \& etc. (2016)[38] suggest that the absorptive capacity of host countries is an influential factor on the reversed technological spillover effect of foreign direct investment. Fei Gao \& et.al (2014)[39] study the correlation between market competition and innovative profit performance of enterprises. And finally, Ruguo Fan \& et.al (2015)[40] argue that technological spillovers of FDI show geographical diversities and lagged effects over time.

\section{STATUS QUo OF ChinA's Foreign Direct InVESTMENT}

For over 30 years of reform and opening-up, China's foreign direct investment has experienced from scratch to full-fledged development. Entering the 21 st century, China began to implement "going out" strategy, the scale and quality has increased significantly, occupying for an important proportion in the global investment. In 2014, China's non-financial outward foreign direct investment reached $\$ 107.2$ billion, rose $15.6 \%$ around a year, the total foreign direct investment (OFDI) amounted to $\$ 123.1$ billion, very close to the actual use of foreign capital (IFDI) of $\$ 128.5$ billion, meaning that China's foreign direct investment has exceeded billions of dollars, becoming one of the world's three biggest foreign direct investors for the first time, and the level of China's two-way (outward and inward) foreign direct investment (FDI) has become in balance. From the perspective of development of industrial distribution over the studying period of 12 years from 2003 to 2015, the outward foreign direct investment (OFDI) in accommodation and catering industry grew fastest by an average of 70 times each year, followed by the industry of information and other services as well as the construction industry, which are 14 times and 13 times at an average annual growth rate, respectively. The annual growth rate of an average of all industries is more than four times over the past 12 years. On the other side, the growth rate of inward foreign direct investment (IFDI) is more stable, the fastest inflow of foreign capitals goes to the financial industry, at an average annual growth rate of 3.5 times, and the 
average annual growth rate of all industries is about $26 \%$. In short, the scale of international direct investment in China has been increasingly enlarged, which is beneficial to promoting the technological progress and economic growth domestically.

Table1. Industrial Distributions of China's International Direct Investments, 2003-2015

\begin{tabular}{|c|c|c|c|c|c|c|c|}
\hline \multirow[t]{2}{*}{ Industries } & \multirow[t]{2}{*}{ code } & \multicolumn{3}{|c|}{ Outward FDI(OFDI)(10thousand USD) } & \multicolumn{3}{|c|}{ Inward FDI(IFDI)(100million USD) } \\
\hline & & Yr. 2003 & Yr. 2015 & $\begin{array}{c}\text { Annual Growth } \\
\text { rate }(\%)\end{array}$ & $\begin{array}{c}\text { Yr. } \\
2003\end{array}$ & Yr. 2015 & $\begin{array}{c}\text { Annual Growth } \\
\text { rate }(\%)\end{array}$ \\
\hline $\begin{array}{l}\text { Agri, forestry, animal } \\
\text { hunsbandry and } \\
\text { fishery }\end{array}$ & $\mathrm{A}$ & 8,316 & 257,208 & $255 \%$ & 119 & 609 & $34 \%$ \\
\hline Mining & $\mathrm{B}$ & 137,866 & $1,125,261$ & $60 \%$ & 39 & 195 & $33 \%$ \\
\hline Manufacturing & $\mathrm{C}$ & 62,404 & $1,998,629$ & $259 \%$ & 6,708 & 19,904 & $16 \%$ \\
\hline $\begin{array}{l}\text { Electricity, gas, water, } \\
\text { prod. \& supply }\end{array}$ & $\mathrm{D}$ & 2,196 & 213,507 & $802 \%$ & 562 & 2,135 & $23 \%$ \\
\hline Construction & $\mathrm{E}$ & 2,278 & 373,501 & $1358 \%$ & 255 & 888 & $21 \%$ \\
\hline Wholesale \& retail & $\mathrm{F}$ & 35,724 & $1,921,785$ & $440 \%$ & 286 & 3,084 & $82 \%$ \\
\hline $\begin{array}{l}\text { Transportation, } \\
\text { Warehousing } \quad \& \\
\text { postal service }\end{array}$ & $\mathrm{G}$ & 7,271 & 272,682 & $286 \%$ & 567 & 1,593 & $15 \%$ \\
\hline $\begin{array}{l}\text { Accommodation \& } \\
\text { Catering }\end{array}$ & $\mathrm{H}$ & 85 & 72,319 & $7082 \%$ & - & 411 & - \\
\hline Financial Ind. & $\mathrm{J}$ & - & $2,424,553$ & - & 36 & 1,543 & $349 \%$ \\
\hline Realestate & $\mathrm{K}$ & - & 778,656 & - & 1,562 & 5,997 & $24 \%$ \\
\hline $\begin{array}{l}\text { Information \& other } \\
\text { services }\end{array}$ & $\mathrm{S}$ & 30,354 & $5,128,613$ & $1400 \%$ & 1,038 & 9,031 & $64 \%$ \\
\hline Total & & 286,764 & $14,566,714$ & $415 \%$ & 11,174 & 45,390 & $26 \%$ \\
\hline
\end{tabular}

Source: *Statistical Bulletin of china's Foreign Investment, 2015* by Ministry of Commerce, China, \& * Statistical Yearbook of China, 2016* by Bureau of Statistics, China

In particular, the effect of China's international direct investment is mainly characterized by the effects of economic growth, technological progress, industrial structural upgrading, and trade promotion. An economic growth effect is mainly reflected by resource allocation, capital accumulation, and technological progress. And the technological spillover can take effects on improving the total factor productivity, thus the enhancement of production outputs. Because main reasons for an outward foreign direct investment for developing countries are to learn foreign advanced technologies and management experiences, which are beneficial to quickly raising the technological level of investors from the reversed technological spillover effect. Thus, the technological spillover effect of foreign direct investment take effects from two aspects, one is a change of productive efficiency or productivity growth through the reversed technological spillover effect; the other is an influential impact on activities of domestic technological innovation. The combination of both aspects will play a positive role in promoting the total factor productivity (TFP). In addition, the foreign direct investment brings to an investing country with more profits for its enterprises by the way of transferring domestic excessive production capacities, extending an industrial life cycle, and thus is helpful for the investing country to make room in developing a hightech industry and a tertiary industry, and in turn to promote the optimization and upgrading of the domestic industrial structure. Finally, the foreign direct investment can circumvent trade barriers, which is also advantageous to have a positive effect on investing countries.

This paper attempts to use a framework of Malmquist productivity growth index to analyze effects of China's FDI in various industries, including both IFDI and OFDI, on the technological progress and the economic growth. And further decompositions of these effective factors are also discussed and studied.

\section{Setup And Measurement Of Theoretical And Empirical Models}

\subsection{Theoretical Basis of Malmquist Productivity Growth Index}

As early as in the 1970s, the Malmquist productivity growth index named after American economist Sten Malmquist (1957) is widely used to measure production efficiency. The basic elements to define 
the Malmquist productivity index are distance functions, which are functional expressions of multiple outputs and multiple inputs. That is to say, for every period $t$, an output distance equation in certain inputs makes the proportion of output as large as possible. To measure the Malmquist productivity index, two different periods must be specified, then the output-based Malmquist productivity growth index of the two consecutive periods are taken for a geometric average value, thus the simplified expression of the resulted index can be specified as follows:

$$
M_{o}^{t+1}\left(x^{t+1}, y^{t+1}, x^{t}, y^{t}\right)=\frac{D_{o}^{t+1}\left(x^{t+1}, y^{t+1}\right)}{D_{o}^{t}\left(x^{t}, y^{t}\right)}\left[\left(\frac{D_{o}^{t}\left(x^{t+1}, y^{t+1}\right)}{D_{o}^{t+1}\left(x^{t+1}, y^{t+1}\right)}\right)\left(\frac{D_{o}^{t}\left(x^{t}, y^{t}\right)}{D_{o}^{t+1}\left(x^{t}, y^{t}\right)}\right)\right]^{\frac{1}{2}} .
$$

By the above expression, the Malmquist productivity index can be broken-down into two components, scale efficiency change (EFFCH) and technological progress (TECHCH). The fraction outside the bracket describes a catch-up effect of relative efficiency increase over the two periods, so called "catching-up" effect; the fraction inside the bracket reflects a cutting-edge effect of technological change, or sometimes referred to as "scientific and technological innovation" effect.

It is worth to note that, the total factor productivity (TFP) defined by the Solow residual identity [41], under the assumption of constant return to scale and Hicks neutral technology, is equal to the growth rate of technological progress. That is to say, the component of technological progress effect (TECHCH) of the Malmquist productivity growth index captures the productivity growth effect caused by input factors, but excluding the scale-efficiency component, therefore should be theoretically equal to the total factor productivity (TFP) in the Solow residual equation. However, because the Solow equation can't eliminate quite many measurement errors, the resulted TFP measure using the Solow residual equation incurs a lot of estimation bias. So, this study uses the component of technological progress factor in the Malmquist productivity growth index to measure the TFP [42].

\subsection{Measurement of the Malmquist Productivity Growth Index}

To calculate the Malmquist productivity growth index of Chinese industries, this study uses the input and output data for 9 sectors and 3 industries of China to build a basic production frontier, then each industry or sector is compared to the benchmark technological frontier to estimate the distances between industrial production and benchmark production for each sector and industry, respectively. And lastly, the industrial Malmquist productivity growth index can be calculated using equation (1).

In the process of estimating distance equations, this paper uses a two-stage optimization linear programming principle. Firstly, it adopts a non-parametric linear programming technique to recover production technology for each industry, and then it re-estimates the distance equation by taking a parametric functional form of trans-logarithmic function to obtain a smooth technological frontier that conforms to the actual production observations the best.

\subsection{Calculation of TFP and Contribution of FDI to Economic Growth}

To measure the contribution of FDI to the technological progress and the economic growth, firstly it is assumed that a country's output $(\mathrm{Y})$, capital $(\mathrm{K})$ and labor $(\mathrm{L})$ inputs, and international direct investment (FDI) are constructed by a Cobb-Douglas (C-D) production function, that is, it takes a functional form as follows:

$$
Y_{t}=A_{t} K_{t}^{\alpha} L_{t}^{\beta} F D I_{t}^{\gamma}
$$

Among them, A represents for the technological level of one country in period t. It is usually assumed that the production is constant return to scale, i.e., $\alpha+\beta=1$. TFP represents for the total factor productivity. $t$ represents for the technological progress of period t. And thus, depending on the Solow residual equation (Solow, 1957)[42], the definition of TFP can be expressed as follows:

$$
T F P_{t}=\frac{Y_{t}}{K_{t}^{\alpha} L_{t}^{\beta}}
$$

Substituting equation (3) into equation (2), then decomposing FDI of the open economy into two factors, an inward foreign direct investment (IFDI) and an outward foreign direct investment (OFDI), and then taking natural logarithms on both sides of the equation, thus the basic econometric function 
for estimating parameters of the TFP equation with respect to the international direct investment can be expressed in the following equation (4). Using appropriate data information, the effects of international direct investment on technological progress for both investing countries and host countries can be analyzed.

$$
\ln T F P_{i t}=\alpha_{0 i}+\alpha_{1 i} \ln O F D I_{i t}+\alpha_{2 i} \ln I F D I_{i t}+\varepsilon_{i t}
$$

Where, TFP it represents for the total factor productivity for the ith industry in year $t$, used to measure technological progress of ith industry; OFDI it is a stock value of the outward foreign direct investment, capturing the foreign direct investment effect overseas; IFDI it is a stock value of the inward foreign direct investment, capturing the actual use of foreign direct investment capitals from abroad.

\section{EMPIRICAL ANALYSIS AND DISCUSSIONS}

\subsection{Data Sources and Analysis}

This paper focuses on analyzing the Malmquist productivity growth index and decomposition effects, including scale efficiency and technological progress effects, at the Chinese industrial level under an open economy framework. Particularly, it focuses on the study of technological spillover effects of the international direct investment, both of OFDI and IFDI, to investing countries and host countries, respectively. Considering the availability and comparability of datasets, the studying period of this paper is set from year 2003 to year 2015.

The basic economic data of Chinese industries, including the annual average GDP, fixed capital stock, labor input and capital investment, the RMB exchange rate and price index, including both fixed asset investment price and GDP deflator, are sourced from the Yearbook of National Bureau of Statistics (2003-2016)[43] and the Bulletin of China's Foreign Investment Statistics (2003-2015)[44]. Accordingly, all data values are converted into constant US dollars in year 2003 with relevant price indexes.

\subsection{Empirical Tests and Analysis}

First of all, based on the principle of Malmquist productivity growth index, this study, by using GAMS, SPSS and STATA statistical software, adopts the two-stage optimization programming method to calculate the productivity growth index for the Chinese sectors and industries over 12 year period from year 2003 to year 2015, and also its two main components of technological progress and scale efficiency change. Table 2 summarizes these results for various sectors and industries and their average values. On average, the annual productivity growth rate of Chinese industries is negative ($2.06 \%$ ) for nearly 12 years, and this is due that its major component of scale efficiency is declined ($3.53 \%$ ). However, the average growth rate of all industries is positive, increasing at an annual growth rate of $1.92 \%$. Besides, differences among industries are still significant, except for the first industry and the finance industry that have an opposite result to an industrial average, other industries are almost consistent with the average level of the development trend of all industries. Note that the productivity growth rate for the first industry and the finance sector are positive, increasing at an annual rate of $2.54 \%$ and $0.32 \%$, respectively, due that their major components of scale effect are positively increased also, at an annual rate of $5.75 \%$ and $1.23 \%$ accordingly. On the contrary, the contribution of technological progress to productivity growth is slightly negative, decreasing at the rate of $-2.62 \%$ and $-0.57 \%$, respectively.

Table2. Productivity Growth, Technological Progress, \& Scale Efficiency of China's Industries, 2003-2015

\begin{tabular}{|l|l|l|l|l|}
\hline \multicolumn{1}{|c|}{ Industries } & Codes & ProdGrth & TechCh & EffCh \\
\hline 1st Industry & $\mathrm{I} 1$ & 1.0254 & 0.9738 & 1.0575 \\
\hline 2nd Industry & $\mathrm{I} 2$ & 0.9765 & 1.0219 & 0.9580 \\
\hline 3rd Industry & $\mathrm{I} 3$ & 0.9888 & 1.0086 & 0.9822 \\
\hline Agri.,forestry,animal hunsbandry and fishery & $\mathrm{A}$ & 0.9660 & 1.0334 & 0.9394 \\
\hline $\begin{array}{l}\text { Basic Industries (Mining, Manufacturing, } \\
\text { Electricity, gas, water prod. \& supply) }\end{array}$ & $\mathrm{BCD}$ & 0.9631 & 1.0358 & 0.9324 \\
\hline Construction & $\mathrm{E}$ & 0.9697 & 1.0288 & 0.9450 \\
\hline Wholesale \& retail & $\mathrm{F}$ & 0.9675 & 1.0319 & 0.9417 \\
\hline
\end{tabular}


The Impact of Foreign Direct Investment (FDI) on Technological Progress and Productivity Growth - A Case Study of Chinese Industries

\begin{tabular}{|l|l|l|l|l|}
\hline Transportation, warehousing \& postal service & $\mathrm{G}$ & 0.9755 & 1.0243 & 0.9581 \\
\hline Accommodation \& catering & $\mathrm{H}$ & 0.9610 & 1.0381 & 0.9276 \\
\hline Financial Ind. & $\mathrm{J}$ & 1.0032 & 0.9943 & 1.0123 \\
\hline Real estate & $\mathrm{K}$ & 0.9675 & 1.0303 & 0.9403 \\
\hline Information \& other services & $\mathrm{S}$ & 0.9881 & 1.0097 & 0.9820 \\
\hline \multirow{2}{*}{0.9820} & $\mathrm{AVG}$ & 0.9794 & 1.0192 & 0.9647 \\
\cline { 2 - 5 } & $\mathrm{I} 1-\mathrm{I} 3$ & 0.9969 & 1.0014 & 0.9992 \\
\cline { 2 - 5 } & $\mathrm{A}-\mathrm{S}$ & 0.9735 & 1.0252 & 0.9532 \\
\hline
\end{tabular}

Notes: Figures in the table are Malmquist productivity growth index and its components of technological progress and efficiency change, computed using GAMS software.

Table3. Variables' Stationarity Tests of Regression Models for China's Industries (I), 2003-2015

\begin{tabular}{|c|c|c|c|c|c|c|c|c|}
\hline & $\begin{array}{l}\text { Ind.A } \\
\text { /Con. }\end{array}$ & $(t, p)$ & $\begin{array}{r}\text { One- } \\
\text { lagged }\end{array}$ & $(t, \quad p)$ & $\begin{array}{l}\text { Ind.F } \\
\text { /Con. }\end{array}$ & $\mathbf{t}, \quad \mathbf{p})$ & $\begin{array}{r}\text { One- } \\
\text { lagged }\end{array}$ & $(t, p)$ \\
\hline In_Malm & 0.8761 & $\begin{array}{r}(3.86, \\
0.005)\end{array}$ & -0.2918 & $(-0.87,0.409)$ & 0.8894 & $\begin{array}{l}4.25 \\
0.003) \\
\end{array}$ & $\begin{array}{c}-0.3102 \\
1.0017 \\
\end{array}$ & $\begin{array}{ll}(-1.00, & 0.344) \\
(50.61, & 0.000)\end{array}$ \\
\hline In_Tech & 0.5277 & $\begin{array}{l}2.02, \\
0.078)\end{array}$ & $\begin{array}{l}0.2641 \\
1.0129\end{array}$ & $\begin{array}{cc}(0.71, & 0.497) \\
(56.92, & 0.000)\end{array}$ & 0.6754 & $\begin{array}{l}(2.71, \\
0.027)\end{array}$ & $\begin{array}{l}0.0523 \\
1.0090\end{array}$ & $\begin{array}{cc}(0.15, & 0.886) \\
(51.67, & 0.000)\end{array}$ \\
\hline ln_Eff & 0.6966 & $\begin{array}{l}(3.97 \\
0.003)\end{array}$ & $\begin{array}{c}-0.0515 \\
0.9640 \\
\end{array}$ & $\begin{array}{ll}-0.20, & 0.846) \\
(30.44, & 0.000) \\
\end{array}$ & 0.8615 & $\begin{array}{l}4.78, \\
0.001)\end{array}$ & $\begin{array}{c}-0.2942 \\
0.9735 \\
\end{array}$ & $\begin{array}{ll}(-1.11, & 0.297) \\
(27.96, & 0.000)\end{array}$ \\
\hline ln_OFDI & 0.2925 & $\begin{array}{l}(1.21 \\
0.254)\end{array}$ & $\begin{array}{l}0.9461 \\
1.0978\end{array}$ & $\begin{array}{cc}(6.92, & 0.000) \\
(19.83, & 0.000) \\
\end{array}$ & 1.3327 & $\begin{array}{l}(2.46, \\
0.034)\end{array}$ & $\begin{array}{l}0.7171 \\
1.0515\end{array}$ & $\begin{array}{cc}(5.07, & 0.000) \\
(22.16, & 0.000)\end{array}$ \\
\hline \multirow[t]{2}{*}{ ln_IFDI } & 0.8579 & $\begin{array}{l}(1.39 \\
0.195)\end{array}$ & $\begin{array}{l}0.8646 \\
1.0205\end{array}$ & $\begin{array}{cc}(7.68, & 0.000) \\
(144.70, & 0.000)\end{array}$ & -0.1614 & $\begin{array}{l}(-0.42, \\
0.687)\end{array}$ & $\begin{array}{l}1.0526 \\
1.0278\end{array}$ & $\begin{array}{cc}(17.57, & 0.000) \\
(170.29, & 0.000)\end{array}$ \\
\hline & $\begin{array}{l}\text { Ind.J } \\
\text { /Con. }\end{array}$ & $(t, p)$ & $\begin{array}{c}\text { One- } \\
\text { lagged }\end{array}$ & $(t, \quad p)$ & \begin{tabular}{|c|} 
Ind.BCD \\
/Con.
\end{tabular} & $(t, \quad p)$ & $\begin{array}{c}\text { One- } \\
\text { lagged }\end{array}$ & $(t, \quad p)$ \\
\hline In_Malm & 0.5883 & $\begin{array}{l}(2.82, \\
0.022)\end{array}$ & $\begin{array}{l}0.1580 \\
1.0071 \\
\end{array}$ & $\begin{array}{cc}(0.53, & 0.614) \\
(118.08, & 0.000)\end{array}$ & 0.8961 & $\begin{array}{l}(4.60) \\
0.002)\end{array}$ & $\begin{array}{c}-0.3242 \\
1.0035\end{array}$ & $\begin{array}{ll}(-1.12, & 0.294) \\
(58.19, & 0.000)\end{array}$ \\
\hline In_Tech & 0.3592 & $\begin{array}{l}(1.86, \\
0.099)\end{array}$ & $\begin{array}{l}0.4852 \\
1.0057\end{array}$ & $\begin{array}{cc}(1.74, & 0.121) \\
(72.26, & 0.000) \\
\end{array}$ & 0.6632 & $\begin{array}{l}(2.70, \\
0.027)\end{array}$ & $\begin{array}{l}0.0717 \\
1.0079\end{array}$ & $\begin{array}{cc}(0.21, & 0.841) \\
(59.75, & 0.000)\end{array}$ \\
\hline ln_Eff & 0.5277 & $\begin{array}{l}(2.95 \\
0.016)\end{array}$ & $\begin{array}{l}0.2424 \\
0.9877\end{array}$ & $\begin{array}{cc}(0.96, & 0.363) \\
(50.52, & 0.000)\end{array}$ & 0.9262 & $\begin{array}{l}(6.06, \\
0.000)\end{array}$ & $\begin{array}{c}-0.4003 \\
0.9778\end{array}$ & $\begin{array}{ll}(-1.76, & 0.113) \\
(32.37, & 0.000)\end{array}$ \\
\hline ln_OFDI & 1.2871 & $\begin{array}{l}(2.06, \\
0.066)\end{array}$ & $\begin{array}{l}0.7287 \\
1.0301 \\
\end{array}$ & $\begin{array}{cc}(4.26, & 0.002) \\
(10.25, & 0.000) \\
\end{array}$ & 1.1220 & $\begin{array}{l}(1.80, \\
0.102) \\
\end{array}$ & $\begin{array}{l}0.7964 \\
1.0391 \\
\end{array}$ & $\begin{array}{cc}(5.82, & 0.000) \\
(39.52, & 0.000) \\
\end{array}$ \\
\hline In_IFDI & 0.5607 & $\begin{array}{l}(1.24 \\
0.243)\end{array}$ & $\begin{array}{l}0.9488 \\
1.0508\end{array}$ & $\begin{array}{ll}(11.31, & 0.000) \\
(60.33, & 0.000) \\
\end{array}$ & 1.3300 & $\begin{array}{l}2.50, \\
0.031)\end{array}$ & $\begin{array}{l}0.8659 \\
1.0077 \\
\end{array}$ & $\begin{array}{l}(15.27, \quad 0.000) \\
595.68, \quad 0.000)\end{array}$ \\
\hline
\end{tabular}

Notes: This table is stationary test results using SPSS and Stata.Industrial codes are same as Table 1.

Secondly, the role of technological progress is reflected in a certain period that, given resources of factor inputs, including labor, capital, land and other series of tangible resources, the growth effect of aggregate outputs of the society resulted from economic activities can also be represented by the growth of total factor productivity (TFP). So, according to the functional equation (4), the effect of international direct investment to the role of technological progress under the condition of open economy is estimated, but also the productivity growth effect and the scale effect as well. As stated earlier, the international direct investment is generally divided into two types of sources, one is an inward foreign direct investment (IFDI) and the other is an outward foreign direct investment (OFDI). The effect of technological progress to host countries of the former is regarded as "the positive technological spillover effect", while that of the investors' home countries of the latter is called "the reversed technological spillover effect". In this paper, both the positive and reversed technological spillover effects of foreign direct investment are analyzed and discussed through the use of China's industrial data for the recent 12 years.

Table4. Variables' Stationarity Tests of Regression Models for China's Industries (II), 2003-2015

\begin{tabular}{|c|c|c|c|c|c|c|c|c|}
\hline & $\begin{array}{l}\text { Ind.G } \\
\text { /Con. }\end{array}$ & $(\mathbf{t}, \mathbf{p})$ & $\begin{array}{c}\text { One- } \\
\text { lagged }\end{array}$ & $(t, \quad p)$ & $\begin{array}{l}\text { Ind.K } \\
\text { /Con. }\end{array}$ & $(\mathbf{t}, \mathbf{p})$ & $\begin{array}{c}\text { One- } \\
\text { lagged }\end{array}$ & $(\mathbf{t}, \quad \mathbf{p})$ \\
\hline In_Malm & 0.8251 & (3.69, & -0.2087 & $(-0.64, \quad 0.543)$ & 0.4289 & $(1.98$ & 0.3710 & $(1.16, \quad 0.281)$ \\
\hline
\end{tabular}


The Impact of Foreign Direct Investment (FDI) on Technological Progress and Productivity Growth - A Case Study of Chinese Industries

\begin{tabular}{|c|c|c|c|c|c|c|c|c|}
\hline & & $0.006)$ & 1.0014 & $(49.73, \quad 0.000)$ & & $0.083)$ & 1.0065 & $(103.99, \quad 0.000)$ \\
\hline In_Tech & 0.5321 & $\begin{array}{l}(2.28 \\
0.052)\end{array}$ & $\begin{array}{l}0.2520 \\
1.0090\end{array}$ & $\begin{array}{cc}(0.76, & 0.470) \\
(50.17, & 0.000)\end{array}$ & 0.5197 & $\begin{array}{l}(2.69 \\
0.027)\end{array}$ & $\begin{array}{l}0.2722 \\
1.0065\end{array}$ & $\begin{array}{cc}(1.00, & 0.348) \\
(85.27, & 0.000)\end{array}$ \\
\hline ln_Eff & 0.7081 & $\begin{array}{l}3.21, \\
0.011) \\
\end{array}$ & $\begin{array}{r}-0.0548 \\
0.9818 \\
\end{array}$ & \begin{tabular}{|ll}
$(-0.17$, & $0.869)$ \\
$(30.20$, & $0.000)$ \\
\end{tabular} & 0.6828 & $\begin{array}{c}(25.17 \\
0.000) \\
\end{array}$ & $\begin{array}{r}-0.0331 \\
1.0116 \\
\end{array}$ & $\begin{array}{ll}-0.77, & 0.461) \\
(11.47, & 0.000) \\
\end{array}$ \\
\hline In_OFDI & 1.9730 & $\begin{array}{l}(4.19, \\
0.002) \\
\end{array}$ & $\begin{array}{l}0.3763 \\
1.0140 \\
\end{array}$ & \begin{tabular}{|cc}
$(2.36$, & $0.040)$ \\
$(13.63$, & $0.000)$
\end{tabular} & 0.5111 & $\begin{array}{c}(1.85, \\
0.095) \\
\end{array}$ & $\begin{array}{l}0.9128 \\
1.1007 \\
\end{array}$ & $\begin{array}{cc}7.67, & 0.000) \\
(16.20, & 0.000)\end{array}$ \\
\hline ln_IFDI & 0.3222 & $\begin{array}{l}0.26 \\
0.797)\end{array}$ & $\begin{array}{l}0.9610 \\
1.0100\end{array}$ & $\begin{array}{cc}5.17, & 0.000) \\
(143.89, & 0.000)\end{array}$ & 0.1191 & $\begin{array}{l}(0.33, \\
0.746)\end{array}$ & $\begin{array}{l}0.9965 \\
1.0117 \\
\end{array}$ & $\begin{array}{cc}(21.93, & 0.000) \\
(565.62, & 0.000)\end{array}$ \\
\hline & $\begin{array}{l}\text { Ind.E } \\
\text { /Con. }\end{array}$ & $(t, p)$ & $\begin{array}{c}\text { One- } \\
\text { lagged }\end{array}$ & $(t, p)$ & $\begin{array}{l}\text { Ind.H } \\
\text { /Con. }\end{array}$ & $(t, p)$ & $\begin{array}{c}\text { One- } \\
\text { lagged }\end{array}$ & $(t, p)$ \\
\hline In_Malm & 0.7716 & $\begin{array}{l}3.65 \\
0.007) \\
\end{array}$ & $\begin{array}{r}-0.1337 \\
1.0035 \\
\end{array}$ & \begin{tabular}{|ll}
$(-0.43$, & $0.679)$ \\
$(57.04$, & $0.000)$ \\
\end{tabular} & 0.6339 & $\begin{array}{c}3.02, \\
0.017) \\
\end{array}$ & $\begin{array}{l}0.0652 \\
1.0093 \\
\end{array}$ & $\begin{array}{cc}(0.21, & 0.840) \\
(58.30, & 0.000) \\
\end{array}$ \\
\hline In_Tech & 0.6604 & $\begin{array}{l}(2.67 \\
0.028)\end{array}$ & $\begin{array}{l}0.0711 \\
1.0081\end{array}$ & $\begin{array}{cc}(0.20, & 0.845) \\
(63.04, & 0.000)\end{array}$ & 0.7657 & $\begin{array}{l}3.18, \\
0.013)\end{array}$ & $\begin{array}{c}-0.0729 \\
1.0024\end{array}$ & $\begin{array}{ll}(-0.22, & 0.835) \\
(63.87, & 0.000)\end{array}$ \\
\hline ln_Eff & 0.7772 & $\begin{array}{l}6.35 \\
0.000) \\
\end{array}$ & $\begin{array}{r}-0.1645 \\
0.9626 \\
\end{array}$ & $\begin{array}{ll}-0.92, & 0.380) \\
(27.24, & 0.000) \\
\end{array}$ & 0.8992 & $\begin{array}{l}(5.90, \\
0.000) \\
\end{array}$ & $\begin{array}{c}-0.3675 \\
0.9836 \\
\end{array}$ & $\begin{array}{ll}(-1.60, & 0.144) \\
(30.83, & 0.000) \\
\end{array}$ \\
\hline In_OFDI & 0.4796 & $\begin{array}{l}(1.66, \\
0.127) \\
\end{array}$ & $\begin{array}{l}0.8823 \\
1.0652 \\
\end{array}$ & $\begin{array}{cc}(6.66, & 0.000) \\
(13.35, & 0.000)\end{array}$ & 0.1042 & $\begin{array}{l}(0.68, \\
0.510)\end{array}$ & $\begin{array}{l}1.1310 \\
1.2687 \\
\end{array}$ & $\begin{array}{ll}(4.11, & 0.002) \\
(6.96, & 0.000) \\
\end{array}$ \\
\hline ln_IFDI & 0.3280 & $\begin{array}{l}(0.42, \\
0.684) \\
\end{array}$ & $\begin{array}{l}0.9589 \\
1.0139 \\
\end{array}$ & $\begin{array}{cc}(7.30, & 0.000) \\
(143.30, & 0.000)\end{array}$ & 1.9365 & $\begin{array}{l}(1.49 \\
0.166) \\
\end{array}$ & $\begin{array}{l}0.6617 \\
1.0031 \\
\end{array}$ & $\left.\begin{array}{cc}(2.89, & 0.016) \\
(273.18, & 0.000)\end{array}\right)$ \\
\hline & \multicolumn{2}{|c|}{ Ind.S /Con. } & \multicolumn{2}{|r|}{$(t, p)$} & \multicolumn{2}{|c|}{ One-lagged } & \multicolumn{2}{|r|}{$(t, p)$} \\
\hline In_Malm & \multicolumn{2}{|c|}{0.8294} & \multicolumn{2}{|c|}{$(3.76, \quad 0.006)$} & \multicolumn{2}{|c|}{$\begin{array}{c}-0.2041 \\
1.0013 \\
\end{array}$} & \multicolumn{2}{|c|}{$\begin{array}{ll}(-0.64, & 0.542) \\
(77.23, & 0.000)\end{array}$} \\
\hline In_Tech & \multicolumn{2}{|c|}{0.3881} & \multicolumn{2}{|c|}{$(1.87, \quad 0.099)$} & \multicolumn{2}{|c|}{$\begin{array}{l}0.4526 \\
1.0113\end{array}$} & \multicolumn{2}{|c|}{$\begin{array}{cc}(1.51, & 0.169) \\
(73.12, & 0.000)\end{array}$} \\
\hline ln_Eff & \multicolumn{2}{|c|}{0.5860} & \multicolumn{2}{|c|}{$(3.16, \quad 0.012)$} & \multicolumn{2}{|c|}{$\begin{array}{l}0.1400 \\
0.9781\end{array}$} & \multicolumn{2}{|c|}{$\begin{array}{cc}(0.53, & 0.611) \\
(45.33, & 0.000)\end{array}$} \\
\hline In_OFDI & \multicolumn{2}{|c|}{1.6273} & \multicolumn{2}{|c|}{$(3.95,0.003)$} & \multicolumn{2}{|c|}{$\begin{array}{l}0.7227 \\
1.0546\end{array}$} & \multicolumn{2}{|c|}{$\begin{array}{cc}(8.22, & 0.000) \\
(26.94, & 0.000)\end{array}$} \\
\hline ln_IFDI & \multicolumn{2}{|c|}{0.0027} & \multicolumn{2}{|c|}{$\begin{array}{ll}0.00, & 0.996)\end{array}$} & \multicolumn{2}{|c|}{$\begin{array}{l}1.0203 \\
1.0207\end{array}$} & \multicolumn{2}{|c|}{$\begin{array}{cc}(13.58, & 0.000) \\
(224.20, & 0.000)\end{array}$} \\
\hline
\end{tabular}

Notes: This table is stationary test results using SPSS and Stata. Industrial codes are same as Table 1.

Since the data used in this study are historical panel datasets, this paper first provides stationary tests for each observational sequence of all variables. The specific results are shown in Table 3 and Table 4. According to the Dick-Fuller testing equation, coefficient parameters of variable sequences of sample observations in the study, which are taken in natural logarithms with one-period lagged equation (excluding constant term) equivalent to the first-order differential equation, are all estimated to be significant, for the p-values of $t$ are less than the critical value at the $1 \%$ significance level. If including constant terms, all variables of the outward foreign direct investment (OFDI) and the inward foreign direct investment (IFDI) are at least significant at the 5\% critical level. Therefore, it is considered that all sequences of involved research variables are stationary, satisfying the cointegration relationship with first-order differences, and thus are no longer needed to have further stationary tests.

Finally, this paper estimates the correlation relationship between foreign direct investment and total factor productivity (TFP), and that of the scale efficiency change (EFFCH) and the productivity growth effect. The specific results are summarized in Table 5 to Table 7, while Table 5 shows the result of technological spillover effects of international direct investment. Except for the variables of Industry BCD (basic production industry), Industry $\mathrm{G}$ (transportation warehousing industry) and Industry $\mathrm{H}$ (accommodation and catering industry), t-values of parameter coefficients of all other variables are significant at least at the 5\% critical level and the adjusted R-squared values are all above 0.95 , so the estimated regression equations fit the sample observations well at a required high degree. In addition, the Durbin-Watson values are all close to 2 , indicating that these fitting equations have no serial correlation. Because the econometric equations are in double logarithms, the 
coefficients of estimated parameters describe the sensitivity or elasticity effects between the dependant variable and its corresponding independent variables. Generally, the elasticity of technological spillover effect of IFDI for China's overall industries are positive, that is, $1 \%$ increase in IFDI level causes nearly $11.4 \%$ improvement of technological level for recent 12 years of the studying period. On the contrary, the outward foreign direct investment of the Chinese enterprises has a negative effect on the domestic technological level decreasing at an about $-3.1 \%$ elasticity rate. In spite of the results of individual industry very close to the overall average level of all industries, the actual values of each industry have quite big differences. Worth noting that the technological spillover effects of two-way foreign direct investment (both IFDI and OFDI) are positive for the three industries, Ind. BCD (basic production industry), Ind. G (transportation and warehousing industry) and Ind. H (accommodation and catering industry), suggesting that all these industries show a positive role in promoting domestic technological progress.

Table5. The Effect of FDI on Technological Progress for China's Industries, 2003-2015

\begin{tabular}{|c|c|c|c|c|c|c|c|c|c|}
\hline In_Tech & In_OFDI & In_IFDI & Adj. $R^{2}$ & DW & In_Tech & In_OFDI & In_IFDI & Adj. $R^{2}$ & DW \\
\hline All Industries & $\begin{array}{l}-.0310 \\
-3.2610 \\
.0015\end{array}$ & $\begin{array}{l}.1140 \\
24.7922 \\
.0000\end{array}$ & .9659 & 2.4983 & Industry $\mathrm{G}$ & $\begin{array}{l}.0040 \\
.1701 \\
.8687\end{array}$ & $\begin{array}{l}.1050 \\
9.4418 \\
.0000\end{array}$ & .9968 & 1.3238 \\
\hline Industry A & $\begin{array}{l}-.0242 \\
-1.5582 \\
.1536\end{array}$ & $\begin{array}{l}.1354 \\
26.2541 \\
.0000\end{array}$ & .9982 & 2.2424 & Industry $\mathrm{H}$ & $\begin{array}{l}.00005 \\
.0025 \\
.9981\end{array}$ & $\begin{array}{l}.1253 \\
67.0719 \\
.0000\end{array}$ & .9990 & 3.1026 \\
\hline Industry BCD & $\begin{array}{l}.0025 \\
.2237 \\
.8280\end{array}$ & $\begin{array}{l}.0742 \\
13.4619 \\
.0000\end{array}$ & .9990 & 2.7978 & Industry J & $\begin{array}{l}-.0508 \\
-2.0402 \\
.0717\end{array}$ & $\begin{array}{l}.1569 \\
9.1034 \\
.0000\end{array}$ & .9788 & .9581 \\
\hline Industry E & $\begin{array}{l}-.0191 \\
-2.5386 \\
.0318\end{array}$ & $\begin{array}{l}.1244 \\
43.6264 \\
.0000\end{array}$ & .9986 & 2.0689 & Industry K & $\begin{array}{l}-.0119 \\
-1.8172 \\
.1026\end{array}$ & $\begin{array}{l}.0929 \\
46.1578 \\
.0000\end{array}$ & .9990 & 1.3104 \\
\hline Industry F & $\begin{array}{l}-.0766 \\
-3.1687 \\
.0114\end{array}$ & $\begin{array}{l}.1538 \\
10.5057 \\
.0000\end{array}$ & .9964 & 1.4257 & Industry $\mathrm{S}$ & $\begin{array}{l}-.0208 \\
-1.8032 \\
.1048\end{array}$ & $\begin{array}{l}.1018 \\
14.1519 \\
.0000\end{array}$ & .9981 & 1.4710 \\
\hline
\end{tabular}

Note: This table is estimation results using SPSS \& Stata. Industrial codes are same as Table 1.

Above empirical results of international direct investment in the study reflect that experiences of China in recent years conform to the traditional investment theory. The foreign direct investment of developed countries to developing countries is often beneficial to the host country's technological progress, and the technological spillover effects are more noticeable in developing nations. On the other hand, the reversed technological spillover effects of overseas foreign direct investment for developing countries is not significant initially, and even have certain negative effects to the investing home country. As a developing country, China's large-scale foreign direct investment is only just beginning. For investing in other developing countries, it mainly focuses on domestic obsolete industries. But for investing in other developed countries, it emphasizes more on accumulating primitive capitals and investing in fixed capitals. But the technological spillover effects of both of these two forms of foreign direct investment are difficult to have a positive effect in a short period to the home investing countries. In the same way, this paper has also analyzed the scale effect and productivity growth effect of China's international direct investment using the similar methods, and their specific results are summarized in Table 6 and Table 7.

\section{Conclusions}

This paper uses the Malmquist productivity growth theory to analyze the technological spillover effect, scale efficiency effect and productivity growth effect of foreign direct investment activities for China's industries over the recent 12 years. It also estimates the sensitivity or elasticity effects of parameter coefficients between IFDI or OFDI and the total factor productivity (TFP) that describe the positive or reversed technological spillover effects, respectively, to the investing country. As the largest developing country, China's large-scale foreign direct investment is only just beginning, for investing in other developing countries, it mainly focuses on domestic obsolete industries, regarded as a resource-seeking typed foreign direct investment, while for investing in other developed countries, it 
emphasizes more on a strategic asset-seeking typed foreign direct investment for the ease of accessing advanced high-end technologies. It is difficult to show a great influence of the reversed technological spillover effect for both of these two forms of foreign direct investment in an early stage, although by contrast, the inward foreign direct investment (IFDI) has an obvious role in promoting the technological level of the hosting country.

To this end, this paper draws an important revelation from the study that, the reversed technological spillover effects of China's outward foreign direct investment have a great potential, so that it should strengthen to increase the proportion of technology-seeking typed foreign direct investment, particularly in developed countries, to improve its own technological level and absorptive ability for advanced technologies, which in turn is beneficial and of realistic significance to promote the total factor productivity, the technological progress, the optimization of industrial structure, and the improvement of comprehensive competitiveness of the investing country.

Table6. Contributions of FDI to Productivity Growth for China's Industries, 2003-2015

\begin{tabular}{|c|c|c|c|c|c|c|c|c|c|}
\hline In_Tech & ln_OFDI & In_IFDI & Adj. R $^{2}$ & DW & In_Tech & In_OFDI & In_IFDI & Adj. $\mathbf{R}^{2}$ & DW \\
\hline All Industries & $\begin{array}{l}-.0293 \\
-3.0543 \\
.0029\end{array}$ & $\begin{array}{l}.1095 \\
23.5628 \\
.0000\end{array}$ & .9625 & 2.5261 & Industry $\mathrm{G}$ & $\begin{array}{l}.0040 \\
.1690 \\
.8695\end{array}$ & $\begin{array}{l}.1013 \\
9.2566 \\
.0000\end{array}$ & .9967 & 1.3363 \\
\hline Industry A & $\begin{array}{l}-.0539 \\
-3.8575 \\
.1536\end{array}$ & $\begin{array}{l}.1385 \\
29.9005 \\
.0000\end{array}$ & .9984 & 2.9283 & Industry $\mathrm{H}$ & $\begin{array}{l}.0083 \\
.4024 \\
.6968\end{array}$ & $\begin{array}{l}.1178 \\
56.1434 \\
.0000\end{array}$ & .9986 & 1.7230 \\
\hline Industry BCD & $\begin{array}{l}.0129 \\
-1.2972 \\
.2268 \\
\end{array}$ & $\begin{array}{l}.0779 \\
15.8380 \\
.0000\end{array}$ & .9991 & 2.8473 & Industry J & $\begin{array}{l}-.0631 \\
-2.2992 \\
.0471 \\
\end{array}$ & $\begin{array}{l}.1653 \\
8.7001 \\
.0000 \\
\end{array}$ & .9746 & 1.0734 \\
\hline Industry E & $\begin{array}{l}-.0305 \\
-3.3855 \\
.0081 \\
\end{array}$ & \begin{tabular}{|l}
.1232 \\
36.0464 \\
.0000 \\
\end{tabular} & .9978 & 1.6725 & Industry K & $\begin{array}{l}-.0147 \\
-2.8030 \\
.0206 \\
\end{array}$ & $\begin{array}{l}.0897 \\
55.5838 \\
.0000 \\
\end{array}$ & .9993 & 1.5648 \\
\hline Industry F & $\begin{array}{l}-.857 \\
-2.4294 \\
.0380\end{array}$ & \begin{tabular}{|l}
.1541 \\
7.2124 \\
.0001 \\
\end{tabular} & .9915 & 1.7410 & Industry S & $\begin{array}{l}-.0403 \\
-4.0087 \\
.0031\end{array}$ & $\begin{array}{l}.1123 \\
17.9412 \\
.0000\end{array}$ & .9985 & .8932 \\
\hline
\end{tabular}

Notes: This table is estimation results using SPSS \& Stata. Industrial codes are same as Table 1.

Table7. The Elasticity Effect of FDI on Scale Efficiency for China's Industries, 2003-2015

\begin{tabular}{|c|c|c|c|c|c|c|c|c|c|}
\hline In_Tech & In_OFDI & In_IFDI & Adj. $R^{2}$ & DW & In_Tech & In_OFDI & In_IFDI & Adj. $\mathbf{R}^{2}$ & DW \\
\hline All Industries & $\begin{array}{l}-.0332 \\
-3.0745 \\
.0027\end{array}$ & $\begin{array}{l}.1096 \\
21.6420 \\
.0000\end{array}$ & .9437 & 2.5261 & Industry $\mathrm{G}$ & $\begin{array}{l}-.0318 \\
-1.4574 \\
.1757\end{array}$ & $\begin{array}{l}.1164 \\
11.8590 \\
.0000\end{array}$ & .9918 & 1.7955 \\
\hline Industry A & $\begin{array}{l}-.1053 \\
-3.2691 \\
.0084\end{array}$ & $\begin{array}{l}.1538 \\
14.8298 \\
.0000\end{array}$ & .9896 & 2.9283 & Industry H & $\begin{array}{l}-.0281 \\
-.7675 \\
.4605\end{array}$ & $\begin{array}{l}.1190 \\
33.2086 \\
.0000\end{array}$ & .9949 & 1.8632 \\
\hline Industry BCD & $\begin{array}{l}.0529 \\
-3.1410 \\
.0105\end{array}$ & $\begin{array}{l}.0963 \\
11.7812 \\
.0000\end{array}$ & .9963 & 2.8473 & Industry $\mathrm{J}$ & $\begin{array}{l}.0958 \\
-3.6089 \\
.0048\end{array}$ & $\begin{array}{l}.1879 \\
10.4258 \\
.0000\end{array}$ & .9694 & 1.6175 \\
\hline Industry E & $\begin{array}{l}-.0605 \\
-4.0079 \\
.0025\end{array}$ & $\begin{array}{l}.1327 \\
24.0748 \\
.0000\end{array}$ & .9927 & 1.6725 & Industry K & $\begin{array}{l}0.409 \\
1.0459 \\
.3202\end{array}$ & $\begin{array}{l}.0681 \\
5.8714 \\
.0002\end{array}$ & .9426 & 1.5232 \\
\hline Industry F & $\begin{array}{l}-.1086 \\
-3.5565 \\
.0052\end{array}$ & $\begin{array}{l}.1654 \\
9.1788 \\
.0000\end{array}$ & .9868 & 1.7410 & Industry S & $\begin{array}{l}-.0627 \\
-6.2555 \\
.0001\end{array}$ & $\begin{array}{l}.1254 \\
20.7427 \\
.0000\end{array}$ & .9969 & 1.6262 \\
\hline
\end{tabular}

Notes: This table is estimation results using SPSS \& Stata. Industrial codes are same as Table 1.

\section{REFERENCES}

[1] Romer, P. M., 1986. Increasing Returns and Long-run Growth. Journal of Political Economy, Vol. 99, pp. 1002-1037.

[2] Lucas, R. E., 1988, “On the Mechanics of Development Planning”, Journal of Monetary Economics, 22: pp. 3-42.

[3] Macdougall, G.D.A. 1960. The Benefits and Costs of Private Investment from Abroad: The Oretical Approach [J]. Economic Record, 36: 13-25. 
[4] Lichtenberg, F., Pottels, B., and Bruno, V. 1996. International R\&D Spillovers: A Re-examination [R]. NBER Working Paper, No. 5668.

[5] Rodriguez, Clare. 1996. Multinational, Linkages, and Economic Development [J]. American Economic Review, 86:852-873.

[6] Perez, T. 1997. Multinational Enterprises and Technological Spillovers: an Evolutionary Model [J]. Evolutionary Economics, 2: 169-192.

[7] Driffield, N. 2001. The Impact on Domestic Productivity of Inward Investment in the UK [D]. The Manchester School.

[8] Javorcik, B.S. 2004. Does Foreign Direct Investment Increases the Productivity of Domestic Firms? Is Search of Spillovers Through Backward Linkages [J]. American Economic Review, 3: 605-627.

[9] Cohen, W., and Levinthal, D. 1990. Absorptive Capacity: A New Perspective on Learning and Innovation [J]. Administrative Science Quarterly, 35: 128-152.

[10] Kiyoshi Kojima. 1987. On the Foreign Trade, translated by Zhou Baolian. Tianjing: Nankai University Press, China, Jan.

[11] Hymer, S. 1960. The International Operations of National Firms :A Study of Direct Foreign Investment [M]. Ph.D. Dissertation Cambridge, MA.

[12] Kindleberger, C.P. 1969. American Business Abroad [M], Yale University Press, pp 10-11.

[13] Buckley, P., M. Casson. 1998. Analyzing foreign market entry strategies: extending the international approach [J]. Journal of International Business Studies, Vol. (3).

[14] Rugman, A. M. 2005. The Regional Multinationals, MNEs and "Global" Strategic Management, Cambridge: Cambridge University Press.

[15] Vernon, R. 1966. International Investment and International Trade in the Product Cycle [J]. Quarterly Journal of Economics, 80: 190-207.

[16] Dunning, J.H. 1973. The determinants of international Production [J], Oxford Economic Papers, 25(3): 289-336.

[17] Coe, D.T. \& Helpman, E. 1995. International R\&D Spillovers [J]. European Economic Review, (39): 859887.

[18] Blomstrom, M., \& Sjoholm, F. 1999. Technology Transfer and Spillovers: Does Local Participation with Multinationals Matter? [J]. European Economic Review, 43: 915-923.

[19] Lichtenberg, F.R. \& Potterie, B.P. 2001. Does Foreign Direct Investment Transfer Technology Across Borders? [J]. The Review of Economics and Statistics, 83(3): 490-497.

[20] Driffield, N., \& Love, J.H. 2003. Foreign Direct Investment, Technology Sourcing and Reverse Spillovers [J]. The Manchester School, 44(2): 315-338.

[21] Chenery, H.B. and Syrquin, Moises. 1980. A Comparative Analysis of Industrial Growth, Chapter in Economic Growth and Resources, edited by R. C. O. Matthews, International Economic Association Series, Palgrave Macmillan UK. pp 223-257.

[22] Wells, L.T. Jr. 1983. Third World Multinationals [M]. Cambridge, MIT Press.

[23] Lall, S. 1983. The New Multinationals. Chichester, John Wiley \& Sons.

[24] Cantwell, J.A., \& Tolentino, P.E.E. 1987. Technological Accumulation and Third World Multinationals, paper presented at the annual meeting of the European International Business Association, Antwerp, December.

[25] Xian Guoming, Rui Yang. 1998. Technological Accumulation, Competition Strategy and Foreign Direct Investment in Developing Countries [J]. Journal of Economic Research, (11): 56-63. (In Chinese)

[26] Ma Yaming, Yangui Zhang. 2003. Technical Advantages and Foreign Direct Investment: An Analysis Framework about the Technological Diffusion [J]. Nankai Economic Research, (4):10-11. (In Chinese)

[27] Du Qunyang, Qin Zhu. 2004. Theory and Practice of Technological Obtaining Foreign Direct Investment of Chinese Enterprises [J]. Journal of International Trade Issues, (11): 66-69. (In Chinese)

[28] Yin, Jian-hua and Xinyue Zhou. 2014. Experience research of China's foreign direct investment - Reverse technological overflow effect based on the technological gap and threshold perspectives [J]. Scientific research management, (3): 131-139. (In Chinese)

[29] Liu, Hongzhong. 2001. The Empirical Study of China's Foreign Direct Investment and International Comparison [M]. Shanghai: Fudan University Press. Pp 52-56.

[30] Gao Minxue, Yingjun Li. 2004. An Empirical Analysis of the Foreign Direct Investment Development Stage: the International Experiences and China's status quo. Management World, Vol. (1). (In Chinese) 
[31] Xue Qiuzhi, Jiqing Zhu. 2007. China's Foreign Direct Investment in the Development Phase of the Empirical Research [J]. Research of the World Economy, (2): 36-40. (In Chinese)

[32] Yang, Jianquan, Xiaowu Yang, Jie Wang. 2006. The Empirical Study of Chins's Foreign Direct Investment: IDP Inspection and Trend Analysis [J]. Journal of International Trade, (8): 76-81. (In Chinese)

[33] Zhang Guangjian, Zhixuan Pan. 2006. Net Foreign Direct Investment in China and Empirical Study of Relationship with China's GDP [J]. Journal of Graduate Student at Zhongnan University of Economics and Law, (3): 33-37. (In Chinese)

[34] Zhao, Wei, Guangdong Gu, Yuanqing He. 2011. Outward FDI and China's Technological Progress: Mechanism Analysis and Attempt Test [J]. Journal of World Economic Studies, (12): 71-77. (In Chinese)

[35] Bai Jie. 2009. Reverse Technology Overflow Effect of Foreign Direct Investment - Empirical Test of the China's Total Factor Productivity [J]. Journal of World Economic Studies, (8): 65-69. (In Chinese)

[36] Zhou, Chunying. 2009. Reverse Foreign Direct Investment Technological Spillovers and Absorptive Capacity Study [J]. Journal of Shanxi University of Finance and Economics, (8): 47-53. (In Chinese)

[37] Zhu Tong, Hao Cui. 2011. Foreign Direct Investment, Reverse R\&D Spillovers and Home Technological Progress: the Mathematical Model and the Empirical Study [J]. Journal of World Economic Studies, (12): 71-77. (In Chinese)

[38] Feng, Ting-ting, Xiangyu Yang, Chen Shen. 2016. Space limitations of FDI technological spillovers for China's Yangtze River Delta region [J]. Journal of technological economy, (6): 71-77. (In Chinese)

[39] Gao, Fei, Yurong Wang, and Xiaohui Liu. 2014. Dual effects of FDI spillovers on the mechanism of innovative catching-up performance - Based on an empirical analysis of the high technological industry [J]. Journal of technological economy, (7): 1-8. (In Chinese)

[40] Fan, Ruguo and Yuxing Meng. 2015. The analysis of regional differences of FDI technological spillover effect on energy efficiency - Based on the perspective of absorptive capacity [J]. Technical Economics, (4): 30-36. (In Chinese)

[41] Solow, R.M., 1957, "Technical Change and the Aggregate Production Function", Review of Economics and Statistics, Vol. 39, pp. 312-20.

[42] Xu, Lan. (2009). Studies of productivity growth index on Yangtze River Delta cities. Shanghai J of Econ, 250(7), pp. 45-53, July. (In Chinese)

[43] Chinese National Bureau of Statistics. 2004-2016. China's Statistical Yearbook [Z]. Beijing: China's Statistics Press.

[44] Chinese Ministry of Commerce. 2004-2015. China's Foreign Direct Investment Statistical Bulletin [Z]. National Bureau of Statistics, State Administration of Foreign Exchange. Beijing: Chinese Statistics Press.

\section{AUTHOR'S BIOGRAPHY}

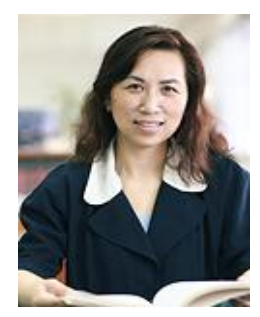

Lan Xu, The author is currently a faculty member of Business School at East China University of Science and Technology (ECUST), whose major fields include applied economics theory, environmental and development economics, finance and managerial economics. She holds a doctorate degree from the applied economics department at University of Minnesota, USA, was also graduated as a master from Humphrey Institute of Public Affairs, University of Minnesota, and a Bachelor from Fudan University in Shanghai, China. She worked as a research fellow in Royal Wilkin Research Center of University of Minnesota, and as a deputy section chief at foreign affairs office of Shanghai Municipal Government.

\footnotetext{
Citation: Lan Xu. "The Impact of Foreign Direct Investment (FDI) on Technological Progress and Productivity Growth - A Case Study of Chinese Industries" International Journal of Managerial Studies and Research (IJMSR), vol 6, no. 10, 2018, pp. 19-32. doi: http://dx.doi.org/10.20431/2349-0349.0610002.

Copyright: (c) 2018 Authors. This is an open-access article distributed under the terms of the Creative Commons Attribution License, which permits unrestricted use, distribution, and reproduction in any medium, provided the original author and source are credited.
} 